\title{
Oncologist
}

\section{Lung $\mathrm{Cancer}$}

\section{Novel Approaches of Chemoradiotherapy in Unresectable Stage IIIA and Stage IIIB Non-Small Cell Lung Cancer}

\author{
Thomas E. StinchCombe, ${ }^{a}$ Jeffrey A. BogarT ${ }^{\mathrm{b}}$

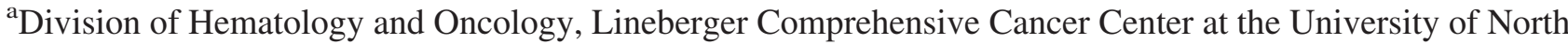 \\ Carolina, Chapel Hill, North Carolina, USA; ${ }^{\mathrm{b}}$ Department of Radiation Oncology, State University of New \\ York Upstate Medical University, Syracuse, New York, USA
}

Key Words. Targeted therapy • Bevacizumab • Epidermal growth factor receptor • Cetuximab • Radiation therapy • Hypofractionation $\bullet$ High-dose thoracic radiation therapy $\bullet$ Adaptive radiotherapy

Disclosures: Jeffrey A. Bogart: Genentech (C/A, RF); Eli Lilly (C/A, RF); GlaxoSmithKline (RF). The other author indicated no financial relationships.

Section Editors: Lecia Sequist: GlaxoSmithKline, Clovis Oncology (C/A); Natasha Leighl: None; Nate Pennell: Oncogenex, Teva (C/A); Pfizer, Genentech, Imclone, Sanofi, Helsinn, CanBas (RF).

Reviewer "A": Amgen, Boehringer-Ingelheim, Aveo, Genentech, Novartis (C/A).

Reviewer "B": None

Reviewer "C": None

(C/A) Consulting/advisory relationship; (RF) Research funding; (E) Employment; (H) Honoraria received; (OI) Ownership interests; (IP) Intellectual property rights/inventor/patent holder; (SAB) Scientific advisory board

\section{LEARNING OBJECTIVES}

After completing this course, the reader will be able to:

1. Describe the current status of phase II trials with novel agents in order to distinguish the role of phase III trials in determining the role of novel agents.

2. Describe target therapy in stage III non-small cell lung cancer and discuss the status of personalized medicine in stage III disease.

3. State the current standard for thoracic radiation therapy and the current status of hypofractionated, adaptive radiotherapy and proton therapy and evaluate the recent radiation therapy oncology group (RTOG) 0617 trial.

\section{GME This article is available for continuing medical education credit at CME.TheOncologist.com.}

\begin{abstract}
Approximately one third of patients with non-small cell lung cancer have unresectable stage IIIA or stage IIIB disease, and appropriate patients are candidates for chemoradiotherapy with curative intent. The optimal treatment paradigm is currently undefined. Concurrent chemoradiotherapy, compared with sequential chemotherapy and thoracic radiation therapy (TRT), results in superior overall
\end{abstract}

survival outcomes as a result of better locoregional control. Recent trials have revealed efficacy for newer chemotherapy combinations similar to that of older chemotherapy combinations with concurrent TRT and a lower rate of some toxicities. Ongoing phase III trials will determine the roles of cisplatin and pemetrexed concurrent with TRT in patients with nonsquamous histology, cetuximab, and the

Correspondence: Thomas E. Stinchcombe, M.D., University of North Carolina at Chapel Hill, 170 Manning Drive, Physician's Office Building, Third Floor, Chapel Hill, North Carolina 27599-7305, USA. Telephone: 919-966-9268; Fax: 919-966-6735; e-mail: Thomas_Stinchcombe@med.unc.edu Received January 11, 2011; accepted for publication March 20, 2012; first published online in The Oncologist Express on April 24, 2012. CAlphaMed Press 1083-7159/2012/\$20.00/0 http://dx.doi.org/10.1634/theoncologist.20120020 
L-BLP25 vaccine. It is unlikely that bevacizumab will have a role in stage III disease because of its toxicity. Erlotinib, gefitinib, and crizotinib have not been evaluated in stage III patients selected based on molecular characteristics. The preliminary results of a phase III trial that compared conventionally fractionated standard-dose TRT (60 Gy) with high-dose TRT (74 Gy) revealed an inferior survival outcome among patients assigned to the high-dose arm. Hyperfractionation was investigated previously with promising results, but adoption has been limited because of logistical considerations. More recent trials have investigated hypofractionated TRT in chemoradiotherapy. Advances in tumor targeting and radiation treatment planning have made this approach more feasible and reduced the risk for normal tissue toxicity. Adaptive radiotherapy uses changes in tumor volume to adjust the TRT treatment plan during therapy, and trials using this strategy are ongoing. Ongoing trials with proton therapy will provide initial efficacy and safety data. The Oncologist 2012; 17:682-693

\section{INTRODUCTION}

Lung cancer is the leading cause of cancer-related mortality in the U.S. and a common cause of cancer-related mortality worldwide $[1,2]$. The majority of patients with lung cancer have the non-small cell lung cancer (NSCLC) subtype, and approximately one third of patients have unresectable stage IIIA or stage IIIB disease [3]. Patients with a preserved performance status, with adequate organ function, and without significant weight loss are candidates for chemoradiotherapy with curative intent. There is significant heterogeneity in the patient population who meet these criteria, which contributes to the variability in the results of clinical trials. Most clinical trials employ a strategy of concurrent chemoradiotherapy for locoregional control and systemic dose chemotherapy to prevent the development of distant metastatic disease. Numerous trials have investigated different agents, treatment sequences, and radiation schedules and doses. Currently, there is no standard of care; combined with the inherent heterogeneity in the patient population, it is therefore difficult for a clinician to select the optimal treatment strategy for an individual patient.

Multiple trials have investigated concurrent chemoradiotherapy versus sequential chemotherapy and thoracic radiation therapy (TRT). A recent meta-analysis of six trials $(1,205$ patients) compared concurrent chemoradiotherapy with sequential chemotherapy followed by TRT. The meta-analysis revealed a significant overall survival (OS) benefit (hazard ratio [HR], 0.84; 95\% confidence interval [CI], 0.74-0.95; $p=$ $.004)$ with an absolute benefit of $4.5 \%$ at 5 years $(15.1 \%$ versus $10.6 \%$ ) [4]. Concurrent chemoradiotherapy resulted in a significantly lower rate of locoregional progression (HR, 0.77 ; $95 \%$ CI, $0.62-0.95 ; p=.01$ ) with a lower rate of local regional progression at 5 years, $28.9 \%$ versus $35.0 \%$. However, the rates of distant disease progression in the concurrent and sequential arms were similar (HR, 1.04; 95\% CI, 0.86-1.25; $p=$ $.69)$ with rates of distant progression of $40.6 \%$ and $39.5 \%$ at 5 years, respectively. Concurrent chemoradiotherapy compared with sequential chemotherapy and TRT was associated with a significantly higher rate of grade 3 or 4 esophageal toxicity, $18 \%$ versus $4 \%$ (relative risk, $4.9 ; 95 \%$ CI, $3.1-7.8 ; p<.001$ ).

This meta-analysis confirmed that the superior OS outcome observed with concurrent chemoradiotherapy was related to better locoregional control. However, the high rates of locoregional and distant disease progression and the low 5 -year OS rate are quite sobering. Thus, improvements in both locoregional and distant disease control are needed to improve
OS outcomes. Several strategies are under investigation, including the use of more recently developed chemotherapy agents, targeted therapy, and novel radiation schedules.

\section{ChemotheraPY AND TARGETED THERAPY CONSIDERATIONS}

\section{Third-Generation Chemotherapy Agents}

Phase III trials that have revealed a statistically significant longer OS with concurrent compared to sequential chemotherapy and radiation have used older chemotherapy combinations of mitomycin, vindesine, and cisplatin (MVP), cisplatin and vinblastine, or cisplatin and etoposide [5-7]. Many clinicians have adopted more recently developed chemotherapy agents based on the perception that these agents have lower toxicity and/or greater efficacy.

Several recent phase III trials have compared the newer combinations with the older combinations (Table 1). A phase III trial recently compared docetaxel and cisplatin weekly with MVP plus concurrent TRT (60 Gy); the primary endpoint was the 2-year OS rate [8]. In the planned analysis, the 2-year OS rate favored the docetaxel and cisplatin arm over the MVP arm (78.8\% versus $70.3 \% ; p=.059$ ); the median survival times (MSTs) were 26.8 months (95\% CI, 23.6-33.4 months) and 23.7 months (95\% CI, 15.8-33.2 months), respectively. The rate of grade 3 or 4 febrile neutropenia was higher in the MVP arm than in the docetaxel and cisplatin arm (39\% versus $22 \%$, respectively), and the rate of grade 3 or 4 esophagitis was higher in the docetaxel and cisplatin arm than in the MVP arm (14\% versus $6 \% ; p=.056)$.

The West Japan Oncology Group Trial 0105 compared MVP with TRT (60 Gy) in two investigational arms: carboplatin plus irinotecan concurrent with TRT followed by two cycles of carboplatin plus irinotecan and carboplatin plus paclitaxel concurrent with TRT followed by two cycles of carboplatin plus paclitaxel (Table 1) [9]. The primary endpoint was the OS time between the control arm (MVP) and the investigational arms of carboplatin plus irinotecan and carboplatin plus paclitaxel. No significant differences in OS times were observed between the investigational arms and MVP, and an analysis did not reveal noninferiority of the investigational arms compared with MVP. The rate of grade 3 or 4 neutropenia, febrile neutropenia, gastrointestinal toxicities (nausea, vomiting, and constipation), and fatigue were significantly higher in the MVP arm than in the carboplatin plus irinotecan or carboplatin plus paclitaxel arms $(p<.001)$. The rate of 
Table 1. Phase III trials of platinum-taxane combinations compared with mitomycin, vindesine, and cisplatin

\begin{tabular}{|c|c|c|c|c|c|}
\hline Authors & $\begin{array}{l}\text { Trial } \\
\text { enrollment }\end{array}$ & Comparisons & $\begin{array}{l}\text { Thoracic } \\
\text { radiation } \\
\text { therapy }(\mathrm{Gy})\end{array}$ & $\begin{array}{l}\text { Median survival } \\
\text { time, months } \\
(95 \% \mathrm{CI})\end{array}$ & $\begin{array}{l}\text { 5-year overall } \\
\text { survival, \% } \\
(95 \% \mathrm{CI})\end{array}$ \\
\hline \multirow{5}{*}{$\begin{array}{l}\text { Segawa } \\
\text { et al. }\end{array}$} & \multirow[t]{5}{*}{200} & Mitomycin $8 \mathrm{mg} / \mathrm{m}^{2}$ on day 1 & \multirow[t]{3}{*}{60} & \multirow[t]{3}{*}{$23.7(15.9-33.2)$} & \multirow[t]{3}{*}{$16.6(8-28.0)$} \\
\hline & & Vindesine $3 \mathrm{mg} / \mathrm{m}^{2}$ on days 1 and 8 & & & \\
\hline & & $\begin{array}{l}\text { Cisplatin } 80 \mathrm{mg} / \mathrm{m}^{2} \text { on day } 1 \\
\text { (every } 4 \text { weeks for } 2 \text { cycles) }\end{array}$ & & & \\
\hline & & Docetaxel $40 \mathrm{mg} / \mathrm{m}^{2}$ on days $1,8,29,36$ & \multirow[t]{2}{*}{60} & \multirow[t]{2}{*}{$26.8(23.6-33.4)$} & \multirow[t]{2}{*}{$23.5(13.8-34.7)$} \\
\hline & & Cisplatin $40 \mathrm{mg} / \mathrm{m}^{2}$ on days $1,8,29,36$ & & & \\
\hline \multirow[t]{6}{*}{$\begin{array}{l}\text { Yamamoto } \\
\text { et al. }\end{array}$} & \multirow[t]{6}{*}{456} & $\begin{array}{l}\text { Concurrent therapy: } \\
\text { Mitomycin } 8 \mathrm{mg} / \mathrm{m}^{2} \text { on day } 1 \\
\text { Vindesine } 3 \mathrm{mg} / \mathrm{m}^{2} \text { on days } 1 \text { and } 8 \\
\text { Cisplatin } 80 \mathrm{mg} / \mathrm{m}^{2} \text { on day } 1 \\
\text { (every } 4 \text { weeks for } 2 \text { cycles) }\end{array}$ & \multirow[t]{2}{*}{60} & \multirow[t]{2}{*}{20.5} & \multirow[t]{2}{*}{17.5} \\
\hline & & $\begin{array}{l}\text { Systemic therapy: } \\
\text { Two additional cycles of MVP }\end{array}$ & & & \\
\hline & & $\begin{array}{l}\text { Concurrent therapy: } \\
\text { Carboplatin AUC }=2 \text { weekly } \\
\text { Irinotecan } 20 \mathrm{mg} / \mathrm{m}^{2} \text { on days } 1,8,15, \\
22,29,36\end{array}$ & \multirow[t]{2}{*}{60} & \multirow[t]{2}{*}{19.8} & \multirow[t]{2}{*}{17.8} \\
\hline & & $\begin{array}{l}\text { Consolidation therapy: } \\
\text { Carboplatin AUC }=5 \text { on day } 1 \\
\text { Irinotecan } 50 \mathrm{mg} / \mathrm{m}^{2} \text { on days } 1 \text { and } 8 \\
\text { (every } 3 \text { weeks for } 2 \text { cycles) }\end{array}$ & & & \\
\hline & & $\begin{array}{l}\text { Concurrent therapy: } \\
\text { Carboplatin AUC }=2 \\
\text { Paclitaxel } 40 \mathrm{mg} / \mathrm{m}^{2} \text { on days } 1,8,15 \text {, } \\
22,29 \text {, and } 36\end{array}$ & \multirow[t]{2}{*}{60} & \multirow[t]{2}{*}{22} & \multirow[t]{2}{*}{19.5} \\
\hline & & $\begin{array}{l}\text { Systemic therapy: } \\
\text { Carboplatin AUC }=5 \text { on day } 1 \\
\text { Paclitaxel } 200 \mathrm{mg} / \mathrm{m}^{2} \text { on day } 1 \\
\text { (every } 3 \text { weeks for } 2 \text { cycles) }\end{array}$ & & & \\
\hline
\end{tabular}

grade 3 sensory neuropathy was higher in the carboplatin plus paclitaxel arm than in the other arms. The rates of grade 3 esophagitis were similar in all treatment arms. In summary, efficacy was not significantly better, but lower rates of some toxicities were observed with the newer agents included in those trials.

Pemetrexed has demonstrated significant activity in patients with advanced stage NSCLC, and it is currently a standard first-line, maintenance, and second-line therapy for patients with nonsquamous histology [10-12]. Several phase II trials have been published reporting results for pemetrexed in combination with cisplatin or carboplatin with concurrent TRT (Table 2) [13-17]. Of note, these trials were performed before the interaction between histology and pemetrexed efficacy was established. Overall, early results have been promising, compared with historical studies, but the ultimate efficacy of pemetrexed cannot be determined based on the phase II trial design, and the longer OS times observed in some of these studies could be related to better staging with ${ }^{18} \mathrm{~F}$-fluoro-2deoxy-D-glucose positron emission tomography (FDG-PET) and patient selection than in prior studies. The rates and types of grade 3 or 4 toxicities reported are similar to the toxicities observed with other chemotherapy combinations used concurrently with TRT. An ongoing phase III trial sponsored by Eli Lilly (ClinicalTrials.gov identifier, NCT00686959) is investigating cisplatin and pemetrexed compared with cisplatin and etoposide with TRT (66 Gy) in patients with nonsquamous histology and will definitively evaluate the role of pemetrexed in the stage III setting [18].

\section{Epidermal Growth Factor Receptor-Targeting Agents}

Two mechanisms of targeting epidermal growth factor receptor (EGFR) pathway have developed: monoclonal antibodies that target the extracellular domain of EGFR and tyrosine kinase inhibitors (TKIs) that compete with ATP for binding to the intracellular domain of EGFR [19]. These agents have been investigated as part of concurrent chemoradiotherapy in several trials (Table 3 ). A phase III trial of cetuximab (a monoclonal antibody that targets EGFR) with radiation compared with radiation alone revealed better locoregional control and a bet- 
Table 2. Phase II trials of platinum and pemetrexed and thoracic radiation for stage III disease

\begin{tabular}{|c|c|c|c|c|}
\hline Authors & Treatment & $\begin{array}{l}\text { Number } \\
\text { of } \\
\text { patients }\end{array}$ & $\begin{array}{l}\text { Thoracic } \\
\text { radiation } \\
\text { therapy } \\
\text { (Gy) }\end{array}$ & $\begin{array}{l}\text { Median overall } \\
\text { survival, } \\
\text { months }(95 \% \\
\text { CI) }\end{array}$ \\
\hline \multirow[t]{2}{*}{ Govindan et al. ${ }^{13}$} & $\begin{array}{l}\text { Arm A: } \\
\text { Carboplatin }(\mathrm{AUC}=5) \\
\text { Pemetrexed }\left(500 \mathrm{mg} / \mathrm{m}^{2}\right) \text { every } \\
21 \text { days }{ }^{\mathrm{a}} \times 4, \text { followed by } \\
\text { pemetrexed }\left(500 \mathrm{mg} / \mathrm{m}^{2}\right) \times 4\end{array}$ & 48 & 70 & 21.2 (17.1-NA) \\
\hline & $\begin{array}{l}\text { Arm B: } \\
\text { Carboplatin }(\mathrm{AUC}=5) \\
\text { Pemetrexed }\left(500 \mathrm{mg} / \mathrm{m}^{2}\right) \\
\text { Cetuximab }^{\mathrm{a}} \times 4 \text { followed by } \\
\text { pemetrexed }\left(500 \mathrm{mg} / \mathrm{m}^{2}\right) \times 4\end{array}$ & 53 & 70 & 25.2 (14.4-NA) \\
\hline Gadgeel et al. ${ }^{14}$ & $\begin{array}{l}\text { Cisplatin }\left(75 \mathrm{mg} / \mathrm{m}^{2}\right) \\
\text { Pemetrexed }\left(500 \mathrm{mg} / \mathrm{m}^{2}\right) \text { every } \\
21 \text { days } \times 3 \text { followed by } \\
\text { docetaxel }\left(75 \mathrm{mg} / \mathrm{m}^{2}\right) \text { every } 21 \\
\text { days } \times 3^{\mathrm{b}}\end{array}$ & 28 & 66 & 34 \\
\hline Xu et al. ${ }^{16}$ & $\begin{array}{l}\text { Carboplatin }(\mathrm{AUC}=5) \\
\text { Pemetrexed }\left(500 \mathrm{mg} / \mathrm{m}^{2}\right) \text { every } \\
21 \text { days } \times 5 \text { cycles }\end{array}$ & 21 & $60-66$ & NA \\
\hline Brade et al. ${ }^{15}$ & $\begin{array}{l}\text { Cisplatin } 20 \mathrm{mg} / \mathrm{m}^{2} \text { on days } 1-5 \\
\text { Pemetrexed }\left(500 \mathrm{mg} / \mathrm{m}^{2}\right) \text { every } \\
21 \text { days } \times 4 \text { cycles }\end{array}$ & 39 & $61-66$ & 19.7 \\
\hline \multirow[t]{2}{*}{ Choy et al. ${ }^{17}$} & $\begin{array}{l}\text { Arm A: } \\
\text { Carboplatin }(\mathrm{AUC}=5) \\
\text { Pemetrexed }\left(500 \mathrm{mg} / \mathrm{m}^{2}\right) \text { every } \\
21 \text { days } \times 3 \text { followed by } \\
\text { pemetrexed } 500 \mathrm{mg} / \mathrm{m}^{2} \times 3\end{array}$ & $34^{\mathrm{c}}$ & $64-68$ & NA \\
\hline & $\begin{array}{l}\text { Arm B: } \\
\text { Cisplatin }\left(75 \mathrm{mg} / \mathrm{m}^{2}\right) \\
\text { Pemetrexed }\left(500 \mathrm{mg} / \mathrm{m}^{2}\right) \times 3 \\
\text { followed by pemetrexed }(500 \\
\left.\mathrm{mg} / \mathrm{m}^{2}\right) \times 3\end{array}$ & $38^{\mathrm{c}}$ & $64-68$ & NA \\
\hline $\begin{array}{l}\text { a The first } 19 \text { patie } \\
\text { bThe first } 5 \text { patien } \\
{ }^{\mathrm{a}} \text { Trial is currently } \\
\text { Abbreviations: AL }\end{array}$ & $\begin{array}{l}\text { ved carboplatin }(\mathrm{AUC}=6) \\
\text { ed cisplatin } 60 \mathrm{mg} / \mathrm{m}^{2} \text {. } \\
\text { ss and still enrolling patients. } \\
\text { under the curve; CI, confidence i }\end{array}$ & +2 & & \\
\hline
\end{tabular}

ter OS result in patients with squamous cancer of the head and neck [20].

For advanced NSCLC, a phase III trial of cisplatin and vinorelbine alone and with cetuximab revealed a statistically significant longer OS time with the addition of cetuximab [21]. The Radiation Therapy Oncology Group (RTOG) trial 0324 was a single-arm, phase II trial that investigated weekly cetuximab, carboplatin, and paclitaxel concurrent with TRT (63 Gy) followed by weekly cetuximab, carboplatin, and paclitaxel every 21 days for two cycles [22]. The median OS time observed was 22.7 months (95\% CI, 15.3-30.4 months). The Cancer and Leukemia Group B (CALGB) 30407 trial investigated carboplatin and pemetrexed alone and with cetuximab concurrent with TRT followed by single-agent pemetrexed [13]. Importantly, this was a nonrandomized phase II trial and was not designed to compare the efficacies of the two treatment arms. The failure-free survival and OS outcomes observed in the two arms were similar. Those trials revealed acceptable toxicity with the addition of cetuximab.

The RTOG 0617 study randomized patients to standarddose or high-dose TRT (60 Gy versus 74 Gy) or carboplatin and paclitaxel alone or with cetuximab concurrent with TRT for two cycles after completion of TRT (ClinicalTrials.gov identifier, NCT00533949) [23]. That trial has completed accrual, and the results from the cetuximab comparison are pending (the results of 60 Gy compared with 74 Gy are discussed later in the article). The role of cetuximab in the treatment of stage III NSCLC will be unclear until the results of the RTOG 0617 trial are available.

The EGFR TKIs erlotinib and gefitinib (not commercially available in the U.S.) are proven agents in the advanced disease setting in patients who have experienced disease progression after chemotherapy and in the first-line setting in patients whose tumors have an activating EGFR mutation [24-29]. 
Table 3. Select trials of EGFR-targeting agents as part of chemoradiotherapy

\begin{tabular}{|c|c|c|c|c|}
\hline First author & Treatment & $\begin{array}{l}\text { Number of } \\
\text { patients }\end{array}$ & $\begin{array}{l}\text { Thoracic } \\
\text { radiation } \\
\text { therapy }(\mathrm{Gy})\end{array}$ & $\begin{array}{l}\text { Median overall } \\
\text { survival, months } \\
(95 \% \mathrm{CI})\end{array}$ \\
\hline \multirow[t]{2}{*}{$\begin{array}{l}\text { Blumenschein } \\
\text { et al. }{ }^{22}\end{array}$} & $\begin{array}{l}\text { Concurrent: } \\
\text { Carboplatin }(\mathrm{AUC}=2), \text { paclitaxel }(45 \\
\left.\mathrm{mg} / \mathrm{m}^{2}\right) \text { weekly and cetuximab }\end{array}$ & 87 & 63 & $22.7(15.3-30.4)$ \\
\hline & $\begin{array}{l}\text { Consolidation: } \\
\text { Carboplatin }(\mathrm{AUC}=6) \text {, paclitaxel }(200 \\
\left.\mathrm{mg} / \mathrm{m}^{2}\right) \text { every } 3 \text { weeks for } 2 \text { cycles, } \\
\text { cetuximab for } 6 \text { weeks }\end{array}$ & & & \\
\hline \multirow[t]{2}{*}{$\begin{array}{l}\text { Govindan } \\
\text { et al. }{ }^{13}\end{array}$} & $\begin{array}{l}\text { Concurrent: } \\
\text { Carboplatin }(\mathrm{AUC}=5), \text { pemetrexed } \\
\left(500 \mathrm{mg} / \mathrm{m}^{2}\right) \text { every } 3 \text { weeks and } \\
\text { cetuximab weekly }^{\mathrm{a}}\end{array}$ & 53 & 70 & $25.2(14.4-N A)$ \\
\hline & $\begin{array}{l}\text { Consolidation: } \\
\text { Pemetrexed } 500 \mathrm{mg} / \mathrm{m}^{2} \text { every } 3 \text { weeks } \\
\text { for } 4 \text { cycles }\end{array}$ & & & \\
\hline \multirow{4}{*}{$\begin{array}{l}\text { Kelly } \\
\text { et al. }\end{array}$} & Concurrent: & Gefitinib: $118^{\mathrm{b}}$ & 61 & 23 \\
\hline & $\begin{array}{l}\text { Cisplatin } 50 \mathrm{mg} / \mathrm{m}^{2} \text { on days } 1,8,28,35 \\
\text { Etoposide } 50 \mathrm{mg} / \mathrm{m}^{2} \text { on days } 1-5,28-33\end{array}$ & Placebo: 125 & & 35 \\
\hline & & & & $(p=0.013)$ \\
\hline & $\begin{array}{l}\text { Consolidation: } \\
\text { Docetaxel } 75 \mathrm{mg} / \mathrm{m}^{2} \text { every } 3 \text { weeks for } 3 \\
\text { cycles }\end{array}$ & & & \\
\hline \multirow{8}{*}{$\begin{array}{l}\text { Ready } \\
\text { et al. }\end{array}$} & Poor risk $^{c}$ & Poor risk: 21 & 66 & 19 \\
\hline & $\begin{array}{l}\text { Induction: } \\
\text { Carboplatin }(\mathrm{AUC}=6) \text {, paclitaxel }(200 \\
\mathrm{mg} / \mathrm{m}^{2} \text { ) every } 3 \text { weeks for } 2 \text { cycles and } \\
\text { gefitinib } 250 \mathrm{mg} \text { daily }\end{array}$ & & & \\
\hline & $\begin{array}{l}\text { Concurrent: } \\
\text { Gefitinib } 250 \mathrm{mg} \text { daily }\end{array}$ & & & \\
\hline & $\begin{array}{l}\text { Consolidation: } \\
\text { Gefitinib } 250 \mathrm{mg} \text { daily }\end{array}$ & & & \\
\hline & Good risk $^{c}$ & Good risk: 39 & & 13 \\
\hline & $\begin{array}{l}\text { Induction: } \\
\text { Carboplatin }(\mathrm{AUC}=6) \text {, paclitaxel }(200 \\
\left.\mathrm{mg} / \mathrm{m}^{2}\right) \text { every } 3 \text { weeks for } 2 \text { cycles and } \\
\text { gefitinib } 250 \mathrm{mg} \text { daily }\end{array}$ & & & \\
\hline & $\begin{array}{l}\text { Concurrent: } \\
\text { Carboplatin }(\text { AUC }=2) \text { and paclitaxel } \\
\left(50 \mathrm{mg} / \mathrm{m}^{2}\right) \text { weekly, gefitinib } 250 \mathrm{mg} \\
\text { daily }\end{array}$ & & & \\
\hline & $\begin{array}{l}\text { Consolidation: } \\
\text { Gefitinib } 250 \mathrm{mg} \text { daily }\end{array}$ & & & \\
\hline \multirow[t]{2}{*}{$\begin{array}{l}\text { Komaki } \\
\text { et al. }{ }^{40}\end{array}$} & $\begin{array}{l}\text { Concurrent: } \\
\text { Carboplatin }(\mathrm{AUC}=2) \text {, paclitaxel }(45 \\
\left.\mathrm{mg} / \mathrm{m}^{2}\right) \text { on Monday, erlotinib } 150 \mathrm{mg} \\
\text { daily Tuesday through Sunday for } 7 \\
\text { weeks }\end{array}$ & 46 & 63 & 25.8 \\
\hline & $\begin{array}{l}\text { Consolidation: } \\
\text { Carboplatin }(\mathrm{AUC}=6) \text { and paclitaxel } \\
\left(200 \mathrm{mg} / \mathrm{m}^{2}\right) \text { for } 2 \text { cycles }\end{array}$ & & & \\
\hline
\end{tabular}

${ }^{\mathrm{a}}$ This data represents one arm of a randomized phase II trials. The first 19 patients on trial received carboplatin $($ AUC $=6)$. ${ }^{b}$ Numbers represent patients randomized to gefitinib or placebo after completion of cisplatin/etoposide and concurrent thoracic radiation therapy and docetaxel.

${ }^{\mathrm{c}}$ Poor risk was defined as $\geq 5 \%$ weight loss and/or performance status of 2 . Good risk was defined as weight loss $<5 \%$ and performance status of $0-1$.

Abbreviation: AUC: area under the curve. 


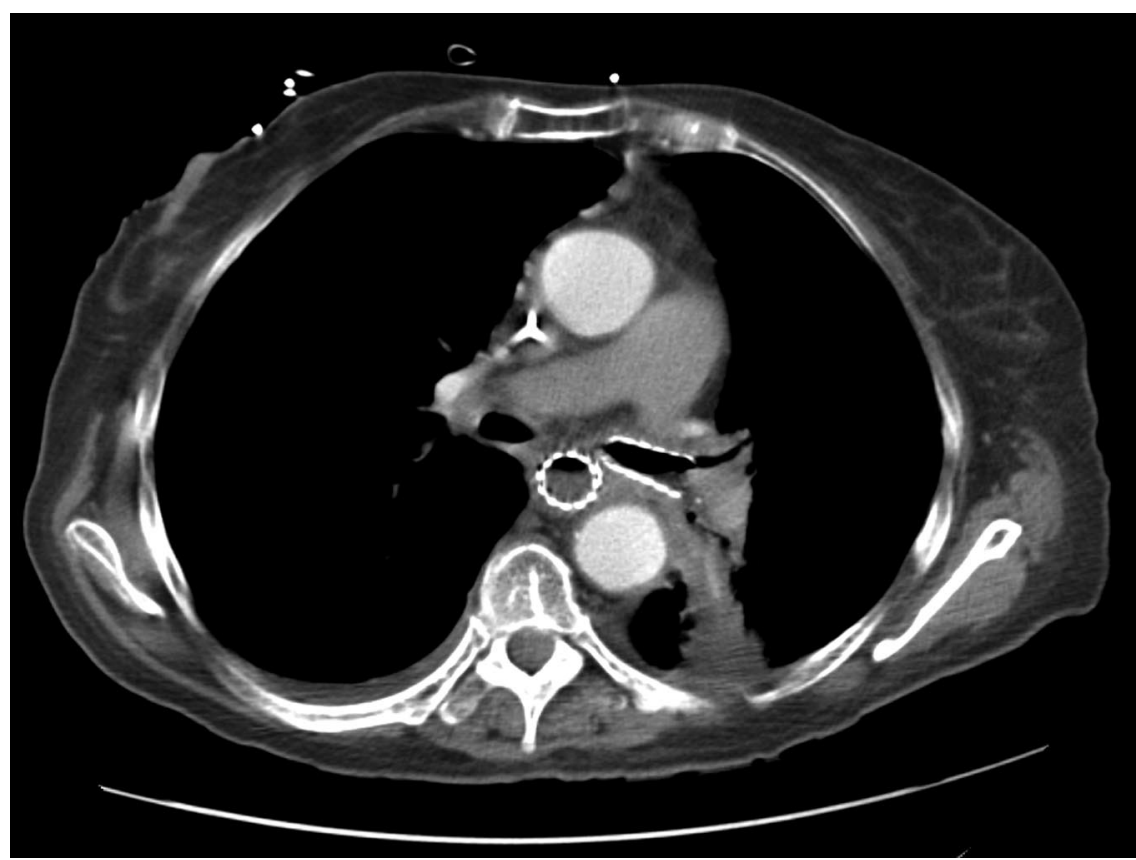

Figure 1. Tracheoesophageal fistula.

The Southwest Oncology Group trial S0023 investigated maintenance gefitinib versus placebo after concurrent chemoradiotherapy with cisplatin and etoposide and TRT and singleagent docetaxel [30]. That trial was closed after an unplanned interim analysis revealed an inferior survival outcome among patients assigned to the gefitinib arm, compared with the placebo arm (HR, 0.633; 95\% CI, 0.44-0.91; $p=.013$; median survival times of 23 months and 35 months, respectively). The shorter survival time was related to tumor progression, and not gefitinib toxicity. A phase III trial investigated erlotinib after concurrent chemoradiotherapy. In the intent-to-treat patient population, no difference in the primary endpoint of the progression-free survival interval, was observed [31]. These trials indicate that EGFR TKI therapy after chemoradiotherapy is unlikely to be beneficial in an unselected patient population and may be detrimental.

EGFR TKIs act as a radiation sensitizer when given with radiation therapy $[32,33]$. Several phase I and II trials have investigated EGFR TKIs in combination with chemotherapy and concurrent TRT in patients who were not selected by clinical or molecular criteria (Table 3) [34-40]. Those trials have not revealed excessive overall toxicity and the OS times observed have been variable, probably reflecting differences in the patients enrolled in the trials. Interstitial pneumonitis is a rare and potentially fatal adverse event of single-agent EGFR TKI therapy, and Japanese patients appear to have a higher risk for this complication [41]. Of note, a higher rate of pulmonary toxicity has been observed in some trials of concurrent EGFR TKIs and TRT [42-44].

The predictive value of activating EGFR mutations has revolutionized the use of these agents in the advanced disease setting. Data on the predictive value of EGFR mutations in the stage III setting are limited. Retrospective data on EGFR mu- tation status are available from the CALGB 30106 trial [39]. The CALGB 30106 study assigned patients to different treatment arms based on performance status and the presence or absence of weight loss. Patients in both cohorts received gefitinib as induction, concurrent, and consolidation therapy; patients in the poor-risk cohort received concurrent TRT and patients in the good-risk cohort received carboplatin, paclitaxel, and gefitinib concurrent with TRT (66 Gy in both cohorts). In all, 13 of the 45 tumors analyzed had an activating EGFR mutation; two of these 13 tumors had T790M mutations detected. In an OS analysis performed on patients with activating EGFR mutations without the T790M mutation $(n=11)$, the median OS time observed was 8.5 months (95\% CI, 5.6-54.4 months); the median survival time in the poor-risk cohort $(n=5)$ was 28.4 months (95\% CI, 5.6-54.4) and the median survival time in the good-risk cohort $(n=6)$ was 7.2 months (95\% CI, 4.7-17.2 months). The poor survival outcome among the small number of patients in the good-risk cohort with an EGFR mutation is concerning given the efficacy of EGFR TKI therapy in advanced-stage disease. There is concern that concurrent chemotherapy and EGFR TKI therapy may be antagonistic, which could be an explanation for the results seen in patients in the good-risk cohort [45]. However, similar outcomes were observed in the advanced-disease setting with erlotinib alone and in combination with chemotherapy among patients with $E G F R$ mutations and those with wild-type EGFR [46].

A phase II trial by Komaki et al. [40] investigated concurrent erlotinib, carboplatin, and paclitaxel with TRT, and an EGFR mutation analysis was performed on 41 tumor samples. $E G F R$ mutations were detected in five samples. The local control rate was significantly higher among patients with an $E G F R$ mutation than among those with wild-type EGFR. Unfortunately, limited data are available on the outcomes of patients 
with stage III disease and a known EGFR mutation treated with chemoradiotherapy or an EGFR TKI concurrent with TRT. In the advanced disease setting, the presence of a mutation is associated with a better prognosis, which further complicates the interpretation of the results.

\section{Bevacizumab}

Phase III trials of platinum-based therapy in combination with bevacizumab compared with platinum-based therapy alone have shown a higher response rate, longer progression-free survival interval, and longer OS time in one trial [47-49]. Preclinical and clinical data suggest that antiangiogenesis therapy and radiation therapy would be additive [50-52]. However, the development of tracheoesophageal fistulae (Fig. 1) in two phase II trials led to early closure of the trials, U.S. Food and Drug Administration warnings, and a change in the bevacizumab package labeling [53]. Of the 25 patients enrolled in the two trials, suspected or confirmed tracheoesophageal fistulae were observed in five patients.

A multicenter phase I/II trial investigated bevacizumab as induction, concurrent, and consolidation therapy $(n=45)$; bevacizumab was used with carboplatin and paclitaxel during induction, alone or with erlotinib depending on the patient cohort during concurrent therapy, and with erlotinib as consolidation therapy [54]. A high rate of grade 3 esophagitis (29\%) was observed, including one tracheoesophageal fistula. The median OS time observed was 18.7 months (95\% CI, 13.4-33.2 months). The data to date with bevacizumab indicate a high rate of toxicity, and the limited efficacy data do not suggest a benefit. It is unlikely that this agent will be developed further in the stage III setting.

\section{Vaccine Therapy}

There has been interest in developing vaccine therapy as a treatment for a variety of stages of NSCLC. Mucin 1 (MUC1) is a protein that is overly expressed in NSCLC with abnormal glycosylation [55]. The BLP25 liposome vaccine (L-BLP25) induces a cellular immune response that may lead to eradication of tumor cells that express MUC1 [55]. A phase IIB trial compared L-BLP25 with best supportive care (BSC) in patients with locally advanced and advanced NSCLC after firstline chemotherapy. In the intent-to-treat population, a statistical difference in the OS time was not observed. However, in the subset of patients with stage IIIB disease (without pleural effusion), a trend toward a better OS outcome in the L-BLP25 arm than in the BSC arm was observed (HR, 0.524; 95\% CI, 0.261-1.052; $p=.069$; the median survival times were not reached and 13.3 months, respectively). The most common treatment-related adverse events observed were grade 1 injection site reactions and flu-like symptoms.

A multinational phase III trial sponsored by Merck KGaA is currently investigating L-BLP25 compared with BSC in patients who have completed chemoradiotherapy (ClinicalTrials.gov identifier, NCT00409188) [56]. Patients are required to have radiographic evidence of stable disease or a response after concurrent or sequential chemotherapy (at least two cycles of platinum-based chemotherapy) and TRT (minimum dose $\geq 50$ Gy). Patients are randomized after completion of chemoradiotherapy, and the planned accrual for this trial is $\sim 1,500$ patients. The primary endpoint is the OS time, and secondary endpoints are time to symptoms and tumor progression. A phase III trial with similar eligibility criteria is being performed in Asia (ClinicalTrials.gov identifier, NCT01015443) and will enroll 420 patients [56].

\section{Personalized Medicine}

For advanced disease, there is great interest in selecting therapies based on biomarkers that are predictive of benefit. The difference between nonsquamous and squamous histology is a commonly used criterion for the selection of agents for advanced disease. It is unclear if the modest improvements in the OS duration observed among patients with nonsquamous histology with pemetrexed in the advanced disease setting [57] will result in substantial improvements in long-term survival outcomes in the stage III setting.

The identification of EGFR mutation for the selection of EGFR TKIs and anaplastic lymphoma kinase rearrangements for the development and selection of crizotinib have revolutionized the treatment of advanced-stage disease [58, 59]. These agents have not been evaluated in the stage III setting in patients selected based on molecular characteristics. The investigation of crizotinib and EGFR TKI therapy in the stage III setting will be difficult because only a small percentage of patients with NSCLC have the associated molecular characteristic, and only a fraction of those patients have stage III disease. It is also unclear if these agents should be given as induction therapy prior to TRT to induce response and reduce tumor volume, alone or with chemotherapy concurrent with TRT, or as consolidation to prevent disease progression. Patients in the control arm will undoubtedly receive these agents at the time of progression, which will confound the OS endpoint. Thus, the integration of these agents to the stage III setting will be challenging.

Of the targeted agents investigated in the stage III setting, cetuximab is furthest in development and the results from the RTOG 0617 trial may be available in the next year. A retrospective analysis of a phase III trial of cisplatin and vinorelbine alone or with cetuximab for advanced disease revealed that a composite score of EGFR immunohistochemistry staining intensity and percentage of tumor cells with EGFR expression was predictive of the benefit of cetuximab; a high score was observed in 345 patients (31\%) and a low score was seen in 776 patients $(69 \%)$ [60]. Among patients with a high score, the addition of cetuximab compared with chemotherapy alone resulted in a superior OS outcome (HR, 0.73; 95\% CI, 058-0.93; $p=.011$; the median OS times were 12.0 months and 9.6 months, respectively). In patients with a low score, no difference in the OS time was observed with the addition of cetuximab compared with chemotherapy alone (HR, 0.99; 95\% CI, $0.84-1.16 ; p=.88$; the median OS times were 9.8 months and 10.3 months, respectively). A treatment interaction test between EGFR score and cetuximab benefit for OS was significant $(p=.044)$. The inevitable question is whether or not the 
benefit of cetuximab in the stage III setting is restricted to patients in the EGFR high-score cohort.

\section{TRT CONSIDERATIONS}

Early results from the RTOG 0617 trial, which compared conventionally fractionated standard-dose $(60 \mathrm{~Gy})$ or high-dose (74 Gy) conformal TRT with concurrent carboplatin and paclitaxel in stage III NSCLC patients, were recently reported [61]. Not only was there a lack of a survival benefit for patients assigned to receive 74 Gy in 2-Gy daily fractions, but there was a trend toward a lower 1-year survival rate in the high-dose arm (1-year OS rate, $81 \%$ versus $70.4 \%$ ). The median OS times observed in the low-dose and high-dose arms were 21.7 months and 20.7 months, respectively $(p=.02)$. The reason for the poor outcomes in the 74-Gy arm has not been clearly elucidated, although greater toxicity was not observed with higher radiation doses. Mature follow-up and assessment of failure patterns are necessary to fully understand the nature of these results, but the strategy of conventional dose escalation via a longer duration of TRT must be called into question.

Although several prospective phase I/II cooperative group studies suggested encouraging OS results with 74-Gy TRT, outcomes may have been biased by the selection of a relatively favorable group of patients, given that these studies were among the first trials to routinely include FDG-PET imaging for staging evaluation [62-64]. In addition, some trials had quite restrictive dose constraints, particularly regarding the allowed exposure of the uninvolved lung volume of $20 \mathrm{~Gy}$ (e.g., V20), which could have led to enrolling patients with relatively limited tumor burdens. It is perhaps sobering to note that the 3 -year OS rate in the standard arm of the recent phase III Hoosier Oncology Group trial was among the best reported, although a lower TRT dose (59.4 Gy) than in contemporaneous studies was given [65].

Despite the lack of benefit noted with high-dose TRT in the RTOG 0617 trial, the relative impact of better local tumor control in a disease ruled by systemic relapse was highlighted in the recent meta-analysis of sequential versus concurrent chemoradiotherapy in stage III NSCLC patients (described earlier) [4]. Both seminal trials that established concurrent therapy as the standard of care also suggested that the superior OS outcome was, in large part, a result of enhanced locoregional control. In the RTOG 94-10 trial, the 2-year infield relapse rate was lower, $30 \%$ versus $39 \%$, whereas the long-term intrathoracic tumor control rate was higher, $50 \%$ versus $35 \%$, in the West Japan Lung Cancer Group Trial [5, 6]. Therefore, it seems that strategies focused on further enhancing local tumor control may translate to meaningful improvements in OS outcomes. However, whether or not modulating the TRT regimen can result in better outcomes as part of combined modality therapy remains to be determined.

Although disappointing, the results of the RTOG 0617 trial add to the body of clinical and preclinical evidence suggesting that extending the duration of conventional radiotherapy may result in diminished efficacy [66]. This was suggested in retrospective analyses of RTOG NSCLC trials [67], and a strikingly similar outcome to that of the RTOG 0617 trial was observed in an intergroup study comparing high-dose and standard-dose radiotherapy concurrent with chemotherapy for locally advanced esophageal cancer [68].

On the other hand, increasing the TRT dose intensity by accelerating the time to complete therapy may be a more attractive strategy. The U.K. trial of continuous hyperfractionated accelerated radiotherapy (CHART), which used $54 \mathrm{~Gy}$ in 36 fractions of 1.5 Gy over 12 consecutive days, is one of the few phase III trials to demonstrate that changing the way TRT is administered can result in a better OS outcome [69]. An absolute $9 \%$ greater 2-year OS rate was demonstrated with CHART compared with conventional TRT (60 Gy).

The Eastern Cooperative Oncology Group studied a variation of CHART, which employed thrice-daily TRT but eliminated therapy during weekends $[70,71]$. In a phase III trial, after two cycles of induction carboplatin and paclitaxel chemotherapy, patients were randomized to standard TRT or HART [71]. Although the trial closed prematurely, the median survival time was 20.3 months for HART, compared with 14.9 months with standard TRT. The difference did not reach statistical significance, but the results with HART compare favorably with those from trials of simultaneous chemoradiotherapy and suggest a potential impact of TRT dose intensity.

The application of HART is limited by the logistic considerations of treating patients multiple times in a day. Moreover, combining CHART with concurrent chemoradiotherapy is challenging in light of the greater acute (esophageal) toxicity observed with hyperfractionated therapy. An alternative approach that has been gaining traction, in large part because of recent advances in technology, is the administration of higher daily doses of radiotherapy, which allows treatment to be completed in fewer fractions (e.g., hypofractionation) than with conventional TRT.

The potential of hypofractionation for locally advanced NSCLC was recognized as early as the 1980s. The RTOG 83-12 trial employed a dose schema of 75 Gy in 2.68-Gy fractions for unresectable (T3/T4) NSCLC [72]. Although rudimentary treatment planning was used, treatment was well tolerated, with outcomes in line with those of contemporaneous studies of primary TRT. Whether or not accelerated hypofractionated TRT and accelerated hyperfractionated TRT have similar efficacies is unclear, although a hypofractionated regimen (55 Gy in 2.75-Gy fractions) appeared equivalent to CHART in a retrospective analysis of patients with unresectable NSCLC in the U.K. [73].

More recent trials have assessed hypofractionated TRT regimens in the context of combined modality therapy. The practical attraction of completing therapy in fewer overall treatments is clear in a system for which machine accessibility and costs are constrained. The European Organization for Research and Treatment of Cancer (EORTC) 08912 trial was a phase I/II study of hypofractionated TRT with concurrent chemotherapy for inoperable patients [74]. Daily cisplatin chemotherapy $\left(6 \mathrm{mg} / \mathrm{m}^{2}\right)$ was administered with $2.75-G y$ fractions, and the TRT dose was escalated from $60.5 \mathrm{~Gy}$ to $66 \mathrm{~Gy}$ without unexpected acute adverse events. Late esophageal toxicity correlated with high-dose (e.g., $55 \mathrm{~Gy}$ ) exposure to the esophagus. 
Table 4. Thoracic radiation therapy (TRT) schema for Cancer and Leukemia Group B Trial 31102 [56]

\begin{tabular}{lllll}
\hline Cohort & $\begin{array}{l}\text { Total } \\
\text { dose } \\
(\mathbf{G y})\end{array}$ & $\begin{array}{l}\text { Fraction } \\
\text { size (Gy) }\end{array}$ & $\begin{array}{l}\text { Total } \\
\text { fractions }\end{array}$ & $\begin{array}{l}\text { TRT } \\
\text { duration } \\
\text { (weeks) }\end{array}$ \\
\hline 1 & 60.0 & 2.22 & 27 & 5.5 \\
2 & 60.0 & 2.50 & 24 & 5 \\
3 & 60.0 & 2.73 & 22 & 4.5 \\
4 & 60.0 & 3.00 & 20 & 4 \\
\hline
\end{tabular}

A subsequent phase III trial (EORTC 08972) randomized 158 patients to receive concurrent daily cisplatin with TRT or two cycles of induction gemcitabine and cisplatin followed by TRT [75]. Radiotherapy consisted of $66 \mathrm{~Gy}$ in 2.75-Gy fractions, with elective nodal irradiation to 40 Gy in 2-Gy fractions. The trial was closed early because of slow accrual, and therefore it was underpowered to detect significant differences in OS outcomes. Nevertheless, the 3-year OS rate was $34 \%$ in patients receiving concurrent treatment, compared with $22 \%$ for patients receiving sequential treatment, thus suggesting a possible long-term benefit. Treatment-related adverse effects in the concurrent arm appeared similar to those in other series of concurrent therapy, although acute toxicity was less in the sequential arm.

A major concern with hypofractionated therapy is the potential higher rate of late effects when large fractions are given to critical normal structures. To address this concern, recent trials of concurrent chemotherapy and hypofractionated TRT have eliminated elective nodal irradiation and instead have focused on intensifying TRT to areas of known tumor. A randomized phase II trial from the U.K. assessed hypofractionated TRT (55 Gy in 2.75-Gy fractions) with concurrent or sequential cisplatin and vinorelbine chemotherapy. Overall, 130 patients with inoperable stage III NSCLC were included in the study [76]. Modern radiotherapy techniques, including fourdimensional treatment planning to assess tumor motion during respiration, were employed. The planning target volume (PTV) was limited to the gross target volume (GTV) plus a margin of $1 \mathrm{~cm}$. With a median follow-up of 25 months, the median survival time for patients receiving concurrent chemotherapy with hypofractionated radiotherapy was 27.4 months, compared with 18.6 months for those receiving sequential treatment. Overall, the toxicity profile of concurrent chemotherapy with hypofractionated chemotherapy was similar to that seen in the sequential arm. However, it is important to note that, in an earlier hypofractionated TRT retrospective series reported by this group, eight of 104 patients required dilatation for esophageal strictures [77].

A single-arm, prospective, phase II study by the Korean Radiation Oncology Group likewise reported encouraging outcomes for hypofractionated TRT and concurrent chemoradiotherapy for patients with unresectable stage III NSCLC [78]. Conformal TRT was given in daily 2.4-Gy fractions with weekly paclitaxel $\left(50 \mathrm{mg} / \mathrm{m}^{2}\right)$ and carboplatin (area under the concentration-time curve of 2) chemotherapy. In that study, PTV expansions from the GTV of $1.5-2.5 \mathrm{~cm}$ were allowed because four-dimensional planning was not routinely used. After a median follow-up of 36.8 months for surviving patients, the median OS time for all 49 study patients was 28.1 months. Severe toxicity appeared limited, although two patients with T4 lesions experienced grade 5 hemoptysis and three patients developed late esophageal strictures.

The previously described trials suggest a greater therapeutic ratio with hypofractionated TRT, but more robust clinical evidence is necessary-particularly given concerns about late associated toxicities. The Alliance for Clinical Trials in Oncology Network cooperative group is scheduled to open a phase I trial assessing hypofractionated RT and weekly carboplatin plus paclitaxel chemotherapy (ClinicalTrials.gov identifier, NCT01486602). That study will use a schema of increasing the dose per fraction while maintaining a constant nominal total dose of $6000 \mathrm{cGy}$, resulting in administration of fewer fractions in each successive patient cohort (Table 4). Excellent local tumor control, with a low rate of severe toxicity, was observed in a prior CALGB trial that employed a similar radiation dose per fraction escalation schema in high-risk earlystage NSCLC patients [79]. Once a maximally tolerated fraction size has been determined, a phase III comparison with conventional TRT will be considered. The integration of advanced technology will be used to minimize expansions of target volumes and help ensure accuracy of treatment in an effort to limit doses to critical normal structures. For example, functional imaging with FDG-PET will be employed for target delineation [80], four-dimensional planning and measures to account for tumor motion will be incorporated, and imageguided radiotherapy will be performed directly prior to each fraction to limit target volume expansion [81]. Intensity-modulated TRT will also be favored to further avoid exposing critical structures to high-dose TRT. Thus, the trial will serve to assess hypofractionated TRT for locally advanced NSCLC in the context of the currently available state-of-the-art advanced technology, with the hope that these results will translate to the general stage III population.

Adaptive radiotherapy (AR) uses changes in tumor volume to adjust the TRT treatment plan during therapy and has been facilitated by the adoption of daily image guidance in many practices. AR should result in better protection of normal structures while ensuring the tumor is adequately dosed. A novel approach to AR - using changes in FDG-PET imaging during concurrent therapy to determine both treatment volume and dose per fraction-will be studied in the RTOG 1106/American College of Radiology Imaging Network 6697 trial [82]. The phase II randomized design will assign patients to receive either standard TRT or AR with the objective of exploring outcomes and toxicity of individualized dose escalation. Treatment in the experimental arm is individualized based on changes in functional imaging obtained midway through treatment, and daily fractions as high as $4.25 \mathrm{~Gy}$ will be permitted for residual PET-avid disease, depending on the predicted toxicity of treatment. Both this trial and the Alliance study will include strict normal tissue constraints, yet at the same time 
they will allow for greater dose inhomogeneity than in prior trials to better spare organs at risk. The relationship between functional imaging characteristics, both at baseline and during therapy, and outcomes will also be assessed. A separate randomized phase II study ongoing in The Netherlands assigns the boost TRT volume based on the region of high FDG-PET avidity seen on pretreatment PET imaging in the experimental arm (ClinicalTrials.gov identifier, NCT01024829) [56]. Hypofractionated TRT of 66 Gy in 2.75-Gy fractions is administered in all patients.

More extreme hypofractionation in the form of stereotactic body radiotherapy (SBRT) has rapidly been adopted into routine clinical practice for high-risk patients with early-stage NSCLC based on excellent outcomes in prospective studies [83]. Although severe toxicity was encountered in early studies after using SBRT for centrally located lesions (e.g., close to major airways and critical mediastinal structures), an ongoing RTOG trial designed specifically for central lesions suggests that a more protracted five-fraction SBRT regimen may be well tolerated (ClinicalTrials.gov identifier, NCT00750269) [84]. Clinical experience using SBRT for locally advanced NSCLC is limited, but preliminary data suggest that adding an SBRT boost for residual disease in patients with stage III NSCLC may be feasible [85]. Additional trials are now assessing the safety and efficacy of SBRT as a boost for residual tumor (based on either anatomic or functional imaging) following induction chemoradiotherapy (ClinicalTrials.gov identifier, NCT00945451 and NCT01222572) [56]. These studies should help determine whether or not SBRT may have a role in the treatment of select patients with stage III NSCLC.

As the development of proton therapy centers has proliferated, experience using proton therapy with concurrent chemotherapy for locally advanced NSCLC is starting to accumulate $[86,87]$. Protons have distinct physical advantages over conventional photon therapy (e.g., Bragg peak), which should allow for better sparing of normal tissues with the potential to reduce toxicity and facilitate hypofractionated therapy. However, the heterogeneity of tissues in the chest, including the interface between air in the lung and both tumor and normal structures, can increase the complexity and uncertainty of proton TRT planning. Retrospective studies published to date should be evaluated with caution given the potential for patient selection, but ongoing prospective trials should provide further data regarding the safety and initial efficacy of proton therapy in locally advanced NSCLC (ClinicalTrials.gov identifier, NCT01076231) [56].

\section{SUMMARY}

Stage III NSCLC continues to be a significant clinical challenge. More recently developed chemotherapy agents appear to have similar efficacies with lower rates of some toxicities. A phase III trial of cisplatin plus pemetrexed with concurrent TRT in patients with nonsquamous histology is ongoing. The RTOG 0617 trial has completed enrollment and results of the comparison for carboplatin and paclitaxel alone and for cetuximab will determine the role of cetuximab in stage III disease. The results of these phase III trials will determine the roles of these agents. Bevacizumab will not have a role in stage III disease based on the observed toxicity, and the targeted agents erlotinib, gefitinib, and crizotinib have yet to be investigated in patients selected based on molecular characteristics. Preliminary results of the comparison of 60 Gy versus 74 Gy as part of the RTOG 0617 trial revealed an inferior OS outcome with the high-dose treatment arm. Hypofractionation, SBRT, AR, and proton therapy are currently being investigated for stage III NSCLC.

\section{Author Contributions}

Conception/Design: Thomas E. Stinchcombe, Jeffrey Bogart

Collection and/or assembly of data: Thomas E. Stinchcombe, Jeffrey Bogart Data Analysis and Interpretation: Thomas E. Stinchcombe, Jeffrey Bogart

Manuscript writing: Thomas E. Stinchcombe, Jeffrey Bogart

Final approval of manuscript: Thomas E. Stinchcombe, Jeffrey Bogart

\section{REFERENCES}

1. Jemal A, Bray F, Center MM et al. Global cancer statistics. CA Cancer J Clin 2011;61:69-90.

2. Parkin DM, Bray F, Ferlay J et al. Global cancer statistics, 2002. CA Cancer J Clin 2005;55:74-108

3. Govindan R, Page N, Morgensztern D et al. Changing epidemiology of small-cell lung cancer in the United States over the last 30 years: Analysis of the surveillance, epidemiologic, and end results database. J Clin Oncol 2006;24:4539-4544.

4. Auperin A, Le Pechoux C, Rolland E et al. Metaanalysis of concomitant versus sequential radiochemotherapy in locally advanced non-small-cell lung cancer. J Clin Oncol 2010;28:2181-2190.

5. Furuse K; West Japan Lung Cancer Group. Phase III study of concurrent versus sequential thoracic radiotherapy in combination with mitomycin, vindesine, and cisplatin in unresectable stage III non-small cell lung cancer. J Clin Oncol 1999;17:2692-2699.

6. Curran WJ Jr, Paulus R, Langer CJ et al. Sequential vs. concurrent chemoradiation for stage III non-small cell lung cancer: Randomized phase III trial RTOG 9410. J Natl Cancer Inst 2011;103:1452-1460.
7. Fournel P, Robinet G, Thomas P et al. Randomized phase III trial of sequential chemoradiotherapy compared with concurrent chemoradiotherapy in locally advanced non-small-cell lung cancer: Groupe Lyon-SaintEtienne d'Oncologie Thoracique-Groupe Francais de Pneumo-Cancerologie NPC 95-01 study. J Clin Oncol 2005;23:5910-5917.

8. Segawa Y, Kiura K, Takigawa N et al. Phase III trial comparing docetaxel and cisplatin combination chemotherapy with mitomycin, vindesine, and cisplatin combination chemotherapy with concurrent thoracic radiotherapy in locally advanced non-small-cell lung cancer: OLCSG 0007. J Clin Oncol 2010;28:3299_ 3306.

9. Yamamoto N, Nakagawa K, Nishimura $\mathrm{Y}$ et al. Phase III study comparing second- and third-generation regimens with concurrent thoracic radiotherapy in patients with unresectable stage III non-small-cell lung cancer: West Japan Thoracic Oncology Group WJTOG0105. J Clin Oncol 2010;28:3739-3745.

10. Scagliotti GV, Parikh P, von Pawel J et al. Phase III study comparing cisplatin plus gemcitabine with cisplatin plus pemetrexed in chemotherapy-naive patients with advanced-stage non-small-cell lung cancer. J Clin Oncol 2008;26:3543-3551.
11. Ciuleanu T, Brodowicz T, Zielinski C et al. Maintenance pemetrexed plus best supportive care versus placebo plus best supportive care for non-small-cell lung cancer: A randomised, double-blind, phase 3 study. Lancet 2009;374:1432-1440.

12. Hanna N, Shepherd FA, Fossella FV et al. Randomized phase III trial of pemetrexed versus docetaxel in patients with non-small-cell lung cancer previously treated with chemotherapy. J Clin Oncol 2004;22:15891597.

13. Govindan R, Bogart J, Stinchcombe T et al. Randomized phase II study of pemetrexed, carboplatin, and thoracic radiation with or without cetuximab in patients with locally advanced unresectable non-small-cell lung cancer: Cancer and Leukemia Group B Trial 30407. J Clin Oncol 2011;29:3120-3125.

14. Gadgeel SM, Ruckdeschel JC, Patel BB et al. Phase II study of pemetrexed and cisplatin, with chest radiotherapy followed by docetaxel in patients with stage III non-small cell lung cancer. J Thorac Oncol 2011;6:927933.

15. Brade AM, Bezjak A, MacRae RM et al. A phase II study of concurrent pemetrexed/cisplatin/radiation (RT) for unresectable stage IIIA/B non-small cell lung cancer (NSCLC). J Clin Oncol 2010;28:7087. 
16. Xu Y, Ma S, Ji Y et al. Concomitant chemoradiotherapy using pemetrexed and carboplatin for unresectable stage III non-small cell lung cancer (NSCLC): Preliminary results of a phase II study. Lung Cancer 2011;72:327-332.

17. Choy H, Schwartzberg LS, Dakhil SR, et al. Ongoing phase II study of pemetrexed plus carboplatin or cisplatin with concurrent radiation therapy followed by pemetrexed consolidation in patients with favorableprognosis inoperable stage IIIA/b non-small cell lung cancer: Interim update [abstract 7082]. J Clin Oncol 2010;28:15s

18. Vokes EE, Senan S, Treat JA et al. PROCLAIM: A phase III study of pemetrexed, cisplatin, and radiation therapy followed by consolidation pemetrexed versus etoposide, cisplatin, and radiation therapy followed by consolidation cytotoxic chemotherapy of choice in locally advanced stage III non-small-cell lung cancer of other than predominantly squamous cell histology. Clin Lung Cancer 2009;10:193-198.

19. Mendelsohn J, Baselga J. Status of epidermal growth factor receptor antagonists in the biology and treatment of cancer. J Clin Oncol 2003;21:2787-2799.

20. Bonner JA, Harari PM, Giralt J et al. Radiotherapy plus cetuximab for squamous-cell carcinoma of the head and neck. N Engl J Med 2006;354:567-578.

21. Pirker R, Pereira JR, Szczesna A et al. Cetuximab plus chemotherapy in patients with advanced non-smallcell lung cancer (FLEX): An open-label randomised phase III trial. Lancet 2009;373:1525-1531.

22. Blumenschein GR Jr, Paulus R, Curran WJ et al. Phase II study of cetuximab in combination with chemoradiation in patients with stage IIIA/B non-small-cell lung cancer: RTOG 0324. J Clin Oncol 2011;29:23122318.

23. Available at http://www.clinicaltrials.gov. Accessed December 29, 2011.

24. Kim ES, Hirsh V, Mok T et al. Gefitinib versus docetaxel in previously treated non-small-cell lung cancer (INTEREST): A randomised phase III trial. Lancet 2008;372:1809-1818.

25. Shepherd FA, Rodrigues Pereira J, Ciuleanu T et al. Erlotinib in previously treated non-small-cell lung cancer. N Engl J Med 2005;353:123-132.

26. Mok TS, Wu YL, Thongprasert S et al. Gefitinib or carboplatin-paclitaxel in pulmonary adenocarcinoma. N Engl J Med 2009;361:947-957.

27. Mitsudomi T, Morita S, Yatabe Y et al. Gefitinib versus cisplatin plus docetaxel in patients with nonsmall-cell lung cancer harbouring mutations of the epidermal growth factor receptor (WJTOG3405): An open label, randomised phase 3 trial. Lancet Oncol 2010;11: 121-128.

28. Maemondo M, Inoue A, Kobayashi K et al. Gefitinib or chemotherapy for non-small-cell lung cancer with mutated EGFR. N Engl J Med 2010;362:23802388.

29. Zhou C, Wu YL, Chen G et al. Erlotinib versus chemotherapy as first-line treatment for patients with advanced EGFR mutation-positive non-small-cell lung cancer (OPTIMAL, CTONG-0802): A multicentre, open-label, randomised, phase 3 study. Lancet Oncol 2011;12:735-742.

30. Kelly K, Chansky K, Gaspar LE et al. Phase III trial of maintenance gefitinib or placebo after concurrent chemoradiotherapy and docetaxel consolidation in inoperable stage III non-small-cell lung cancer: SWOG S0023. J Clin Oncol 2008;26:2450-2456.

31. Rigas JR, Carey MA, Rubin MS et al. Efficacy of maintenance erlotinib versus placebo in patients with unresectable stage III non-small cell lung cancer (NSCLC) following concurrent chemoradiation (D0410, NCT001538803). J Thorac Oncol 2009;4:s371.

32. Raben D, Helfrich B, Chan D et al. ZD1839, a selective epidermal growth factor receptor tyrosine kinase inhibitor, alone and in combination with radiation and chemotherapy as a new therapeutic strategy in non-small cell lung cancer. Semin Oncol 2002;29:37-46.

33. Chinnaiyan $P$, Huang $S$, Vallabhaneni $G$ et al. Mechanisms of enhanced radiation response following epidermal growth factor receptor signaling inhibition by erlotinib (Tarceva). Cancer Res 2005;65:3328-3335

34. Stinchcombe TE, Morris DE, Lee CB et al. Induction chemotherapy with carboplatin, irinotecan, and paclitaxel followed by high dose three-dimension conformal thoracic radiotherapy (74 Gy) with concurrent carboplatin, paclitaxel, and gefitinib in unresectable stage IIIA and stage IIIB non-small cell lung cancer. J Thorac Oncol 2008;3:250-257.

35. Choong NW, Mauer AM, Haraf DJ et al. Phase I trial of erlotinib-based multimodality therapy for inoperable stage III non-small cell lung cancer. J Thorac Oncol 2008;3:1003-1011.

36. Ball D, Burmeister B, Mitchell $P$ et al. Phase I trial of gefitinib in combination with concurrent carboplatin, paclitaxel and radiation therapy in patients with stage III non small cell lung cancer ("CRITICAL"): P2-162. J Thorac Oncol 2007;2:S633-S634.

37. Center B, Petty WJ, Ayala D et al. A phase I study of gefitinib with concurrent dose-escalated weekly docetaxel and conformal three-dimensional thoracic radiation followed by consolidative docetaxel and maintenance gefitinib for patients with stage III nonsmall cell lung cancer. J Thorac Oncol 2010;5:69-74.

38. Rothschild S, Bucher SE, Bernier J et al. Gefitinib in combination with irradiation with or without cisplatin in patients with inoperable stage III non-small cell lung cancer: A phase I trial. Int J Radiat Oncol Biol Phys 2011;80:126-132.

39. Ready N, Janne PA, Bogart J et al. Chemoradiotherapy and gefitinib in stage III non-small cell lung cancer with epidermal growth factor receptor and KRAS mutation analysis: Cancer and leukemia group B (CALEB) 30106, a CALGB-stratified phase II trial. J Thorac Oncol 2010;5:1382-1390.

40. Komaki R, Blumenschein GR, Wistuba II et al. Phase II trial of erlotinib and radiotherapy following chemoradiotherapy for patients with stage III non-small cell lung cancer. J Clin Oncol 2011;29:7020.

41. Yoneda KY, Hardin KA, Gandara DR et al. Interstitial lung disease associated with epidermal growth factor receptor tyrosine kinase inhibitor therapy in nonsmall-cell lung carcinoma. Clin Lung Cancer 2006;8: S31-S35.

42. Wan J, Cohen V, Agulnik J et al. Unexpected high lung toxicity from radiation pneumonitis in a phase I/II trial of concurrent erlotinib with limited field radiation for intermediate prognosis patients with stage III or inoperable stage IIB non-small-cell lung cancer (NSCLC). Int J Radiat Oncol Biol Phys 2009;75:S110.

43. Okamoto I, Takahashi T, Okamoto $\mathrm{H}$ et al. Singleagent gefitinib with concurrent radiotherapy for locally advanced non-small cell lung cancer harboring mutations of the epidermal growth factor receptor. Lung Cancer 2011;72:199-204.

44. Ohe Y, Nishiwaki Y, Yokoyama A et al. Safety and efficacy trial of cisplatin $(\mathrm{P})$ with vinorelbine $(\mathrm{V})$ followed by gefitinib $(\mathrm{G})$ and concurrent thoracic radiotherapy (TRT) for unresectable locally advanced non-small cell lung cancer (LA-NSCLC): Japan Clinical Oncology Group (JCOG) 0402. J Clin Oncol 2010;28:7084.

45. Davies AM, Ho C, Lara PN Jr et al. Pharmacodynamic separation of epidermal growth factor receptor ty- rosine kinase inhibitors and chemotherapy in non-smallcell lung cancer. Clin Lung Cancer 2006;7:385-388.

46. Janne PA, Wang XF, Socinski MA et al. Randomized phase II trial of erlotinib (E) alone or in combination with carboplatin/paclitaxel (CP) in never or light former smokers with advanced lung adenocarcinoma: CALGB 30406. J Clin Oncol 2010;28:7503.

47. Sandler A, Gray R, Perry MC et al. Paclitaxelcarboplatin alone or with bevacizumab for non-smallcell lung cancer. N Engl J Med 2006;355:2542-2550.

48. Reck M, von Pawel J, Zatloukal P et al. Phase III trial of cisplatin plus gemcitabine with either placebo or bevacizumab as first-line therapy for nonsquamous nonsmall-cell lung cancer: AVAil. J Clin Oncol 2009;27: 1227-1234.

49. Reck M, von Pawel J, Zatloukal P et al. Overall survival with cisplatin-gemcitabine and bevacizumab or placebo as first-line therapy for nonsquamous nonsmall-cell lung cancer: Results from a randomised phase III trial (AVAiL). Ann Oncol 2010;21:1804-1809.

50. Willett CG, Boucher Y, di Tomaso E et al. Direct evidence that the VEGF-specific antibody bevacizumab has antivascular effects in human rectal cancer. Nat Med 2004;10:145-147

51. Gorski DH, Mauceri HJ, Salloum RM et al. Potentiation of the antitumor effect of ionizing radiation by brief concomitant exposures to angiostatin. Cancer Res 1998;58:5686-5689.

52. Mauceri HJ, Hanna NN, Beckett MA et al. Combined effects of angiostatin and ionizing radiation in antitumour therapy. Nature 1998;394:287-291.

53. Spigel DR, Hainsworth JD, Yardley DA et al. Tracheoesophageal fistula formation in patients with lung cancer treated with chemoradiation and bevacizumab. J Clin Oncol 2010;28:43-48.

54. Stinchcombe T, Socinski MA, Moore DT et al. Phase I/II trial of bevacizumab (B) and erlotinib (E) with induction (IND) and concurrent (CON) carboplatin $(\mathrm{Cb}) /$ paclitaxel $(\mathrm{P})$ and $74 \mathrm{~Gy}$ of thoracic conformal radiotherapy (TCRT) in stage III non-small cell lung cancer (NSCLC) [abstract 7082]. J Clin Oncol 2010;28:15s.

55. Butts C, Murray N, Maksymiuk A et al. Randomized phase IIB trial of BLP25 liposome vaccine in stage IIIB and IV non-small-cell lung cancer. J Clin Oncol 2005;23:6674-6681.

56. Available at http://www.clinicaltrials.gov. Accessed February 19, 2012

57. Scagliotti G, Hanna N, Fossella F et al. The differential efficacy of pemetrexed according to NSCLC histology: A review of two Phase III studies. Oncologist 2009; 14:253-263.

58. Kwak EL, Bang YJ, Camidge DR et al. Anaplastic lymphoma kinase inhibition in non-small-cell lung cancer. N Engl J Med 2010;363:1693-1703.

59. Azzoli CG, Baker S, Jr. Temin $S$ et al. American Society of Clinical Oncology Clinical Practice Guideline update on chemotherapy for stage IV non-small-cell lung cancer. J Clin Oncol 2009;27:6251-6266.

60. Pirker R, Pereira JR, von Pawel J, et al. EGFR expression as a predictor of survival for first-line chemotherapy plus cetuximab in patients with advanced nonsmall-cell lung cancer: Analysis of data from the phase 3 FLEX study. Lancet Oncol 2012;13:33-42.

61. Bradley JD, Paulus R, Komaki R, et al. A randomized phase III comparison of standard-dose ( $60 \mathrm{~Gy}$ ) versus high-dose (74 Gy) conformal chemoradiotherapy \pm cetuximab for stage IIIa/IIIb non-small cell lung cancer: Preliminary findings on radiation dose in RTOG 0617. Presented at the 53rd ASTRO Annual Meeting, Miami Beach, Florida, October 3, 2011.

62. Socinski MA, Blackstock AW, Bogart JA et al. 
Randomized phase II trial of induction chemotherapy followed by concurrent chemotherapy and dose-escalated thoracic conformal radiotherapy $(74 \mathrm{~Gy})$ in stage III non-small-cell lung cancer: CALGB 30105. J Clin Oncol 2008;26:2457-2463.

63. Schild SE, McGinnis WL, Graham D et al. Results of a Phase I trial of concurrent chemotherapy and escalating doses of radiation for unresectable non-small-cell lung cancer. Int J Radiat Oncol Biol Phys 2006;65: 1106-1111.

64. Bradley JD, Bae K, Graham MV et al. Primary analysis of the phase II component of a phase I/II dose intensification study using three-dimensional conformal radiation therapy and concurrent chemotherapy for patients with inoperable non-small-cell lung cancer: RTOG 0117. J Clin Oncol 2010;28:2475-2480.

65. Hanna N, Neubauer M, Yiannoutsos $C$ et al. Phase III study of cisplatin, etoposide, and concurrent chest radiation with or without consolidation docetaxel in patients with inoperable stage III non-small-cell lung cancer: The Hoosier Oncology Group and U.S. Oncology. J Clin Oncol 2008;26:5755-5760.

66. Fowler JF, Chappell R. Non-small cell lung tumors repopulate rapidly during radiation therapy. Int J Radiat Oncol Biol Phys 2000;46:516-517.

67. Cox JD, Pajak TF, Asbell S et al. Interruptions of high-dose radiation therapy decrease long-term survival of favorable patients with unresectable non-small cell carcinoma of the lung: Analysis of 1244 cases from 3 Radiation Therapy Oncology Group (RTOG) trials. Int J Radiat Oncol Biol Phys 1993;27:493-498.

68. Minsky BD, Pajak TF, Ginsberg RJ et al. INT 0123 (Radiation Therapy Oncology Group 94-05) phase III trial of combined-modality therapy for esophageal cancer: High-dose versus standard-dose radiation therapy. J Clin Oncol 2002;20:1167-1174.

69. Saunders M, Dische S, Barrett A et al. Continuous hyperfractionated accelerated radiotherapy (CHART) versus conventional radiotherapy in non-small-cell lung cancer: A randomised multicentre trial. CHART Steering Committee. Lancet 1997;350:161-165.

70. Mehta MP, Tannehill SP, Adak S et al. Phase II trial of hyperfractionated accelerated radiation therapy for nonresectable non-small-cell lung cancer: Results of
Eastern Cooperative Oncology Group 4593. J Clin Oncol 1998;16:3518-3523.

71. Belani CP, Wang W, Johnson DH et al. Phase III study of the Eastern Cooperative Oncology Group (ECOG 2597): Induction chemotherapy followed by either standard thoracic radiotherapy or hyperfractionated accelerated radiotherapy for patients with unresectable stage IIIA and B non-small-cell lung cancer. J Clin Oncol 2005;23:3760-3767.

72. Graham MV, Pajak TE, Herskovic AM et al. Phase I/II study of treatment of locally advanced (T3/T4) nonoat cell lung cancer with concomitant boost radiotherapy by the Radiation Therapy Oncology Group (RTOG 8312): Long-term results. Int J Radiat Oncol Biol Phys 1995;31:819-825.

73. Pemberton LS, Din OS, Fisher PM et al. Accelerated radical radiotherapy for non-small cell lung cancer using two common regimens: A single-centre retrospective study of outcome. Clin Oncol (R Coll Radiol) 2009; 21:161-167.

74. Uitterhoeve AL, Belderbos JS, Koolen MG et al. Toxicity of high-dose radiotherapy combined with daily cisplatin in non-small cell lung cancer: Results of the EORTC 08912 phase I/II study. European Organization for Research and Treatment of Cancer. Eur J Cancer 2000;36:592-600.

75. Belderbos J, Uitterhoeve L, van Zandwijk N et al. Randomised trial of sequential versus concurrent chemo-radiotherapy in patients with inoperable nonsmall cell lung cancer (EORTC 08972-22973). Eur J Cancer 2007;43:114-121.

76. Maguire J. SOCCAR: Sequential or concurrent chemotherapy and hypofractionated accelerated radiotherapy in inoperable stage III NSCLC. J Clin Oncol 2011;29:7039.

77. Maguire JLM, Walshaw M. Enhanced local control and survival with concurrent chemoradiation using accelerated hypofractionated radiotherapy. Presented at the Multidisciplinary Thoracic Oncology Meeting, Chicago, Illinois, December 9-11, 2010.

78. Cho KH, Ahn SJ, Pyo HR et al. A Phase II study of synchronous three-dimensional conformal boost to the gross tumor volume for patients with unresectable Stage III non-small-cell lung cancer: Results of Korean Radi- ation Oncology Group 0301 study. Int J Radiat Oncol Biol Phys 2009;74:1397-1404.

79. Bogart JA, Hodgson L, Seagren SL et al. Phase I study of accelerated conformal radiotherapy for stage I non-small-cell lung cancer in patients with pulmonary dysfunction: CALGB 39904. J Clin Oncol 2010;28:202206.

80. Mac Manus MP, Hicks RJ, Ball DL et al. F-18 fluorodeoxyglucose positron emission tomography staging in radical radiotherapy candidates with nonsmall cell lung carcinoma: Powerful correlation with survival and high impact on treatment. Cancer 2001;92:886-895.

81. Bujold A, Craig T, Jaffray D et al. Image-guided radiotherapy: Has it influenced patient outcomes? Semin Radiat Oncol 2012;22:50-61.

82. Kong F-MS, Xiao Y, Machtay M et al. Using during-RT PET to individualize adaptive RT for patients with stage III NSCLC: A RTOG planning study [abstract 2818]. Presented at the American Society for Radiation Oncology 2011 Annual Meeting, Miami Beach, Florida, October 2-6, 2011.

83. Timmerman R, Paulus R, Galvin J et al. Stereotactic body radiation therapy for inoperable early stage lung cancer. JAMA 2010;303:1070-1076.

84. Timmerman R, McGarry R, Yiannoutsos $C$ et al. Excessive toxicity when treating central tumors in a phase II study of stereotactic body radiation therapy for medically inoperable early-stage lung cancer. J Clin Oncol 2006;24:4833-4839.

85. Feddock J, McGarry R. Safety and toxicity of linac-based stereotactic body radiotherapy (SBRT) boost to residual disease in locally advanced non-small cell lung cancer: Preliminary results of a single institution feasibility study. Int J Radiat Oncol Biol Phys 2010; 78:s108.

86. Bush DA. Proton radiation therapy for lung cancer: Is there enough evidence? Oncology (Williston Park) 2010;24:1052-1057.

87. Widesott L, Amichetti M, Schwarz M. Proton therapy in lung cancer: Clinical outcomes and technical issues. A systematic review. Radiother Oncol 2008; 86:154-164. 